\title{
Obesity: should there be a law against it? Introduction to a symposium Roger S Magnusson
}

\author{
Address: Faculty of Law, University of Sydney, Sydney, Australia
}

Email: Roger S Magnusson - R.Magnusson@usyd.edu.au

Published: 5 June 2008

Australia and New Zealand Health Policy 2008, 5:9 doi:I 0.I 186/I743-8462-5-9

This article is available from: http://www.anzhealthpolicy.com/content/5/I/9

(c) 2008 Magnusson; licensee BioMed Central Ltd.

This is an Open Access article distributed under the terms of the Creative Commons Attribution License (http://creativecommons.org/licenses/by/2.0), which permits unrestricted use, distribution, and reproduction in any medium, provided the original work is properly cited.

Received: 12 November 2007

Accepted: 5 June 2008

\begin{abstract}
The rapid rise in rates of overweight and obesity among adults and children in Australia and New Zealand has intensified debate about the most effective policies for obesity prevention. Law has much to contribute to this policy discussion, although its role is often misunderstood. The articles in this symposium follow on from a conference hosted in September 2006 by the Centre for Health Governance, Law \& Ethics in the Faculty of Law, University of Sydney, titled: Obesity: should there be a law against it? In different ways, these articles provide a variety of perspectives on regulatory responses to obesity, including theoretical justifications for a legal approach, conceptual models that assist in making sense of law's role, as well as specific legal strategies for obesity prevention in various settings.
\end{abstract}

\section{Editorial}

What can law do about obesity? Law's role in preventing and reversing weight gain at the population level has become a serious topic of discussion among public health lawyers and policy-makers. In the United States, there has been tremendous interest in the extent to which food and beverage companies could be vulnerable to tobacco-style lawsuits brought by obese claimants for the health effects of obesity and chronic diseases [1-5]. Legal interest has broadened as lawyers have begun to consider the role that law might play as a policy tool in obesity prevention efforts. Law's capacity to address childhood obesity, including school-based interventions, and the regulation of advertising, has emerged as an important theme in the literature [6-8]. Parliamentary inquiries - most recently in New Zealand - have proposed policies for the future $[9,10]$. Legislatures, meanwhile, at least in the United States, have not stood still, and recent reviews (including Hodge, Garcia and Shaw in this symposium) demonstrate the wide range of laws that have already been introduced as part of obesity prevention efforts [11-13].

Public health scholars have long recognized, although sometimes implicitly, a role for law in policy approaches to obesity and chronic diseases generally [14-20]. Growing interest in these issues among public health lawyers themselves is therefore timely and appropriate.

\section{Obesity - should there be a law against it?}

The articles in this symposium aim to open up the debate about law and obesity for lawyers and non-lawyers alike, with specific reference to Australia, but informed by experience in the United States and Britain. Early versions of some of the articles in this series were originally presented at a conference hosted by the University of Sydney Faculty of Law in September 2006, provocatively entitled: Obesity: should there be a law against it? This conference elicited a strong reaction, with some people writing in from around the world to condemn the conference as yet more evi- 
dence of discrimination against obese people. Ironically, it is those who are most opposed to a role for law in the regulation of obesity and chronic disease who have raised (facetiously) the prospect of policies that would tax citizens for their extra kilos [21], or frankly advocated ramping up health insurance premiums for the overweight in order to eliminate the subsidies that thin people pay overweight people through community rated schemes [22].

By extending their gaze beyond the proximate, behavioural determinants of obesity, policy-makers who adopt a population health perspective have a far broader range of policies to choose from. By acknowledging the reality of socioeconomic and environmental influences upon patterns of eating and physical activity, a population health perspective is more sensitive to the challenges that individuals face, and is more likely to avoid legal approaches that are punitive and discriminatory.

\section{Law and obesity: three broad themes}

The title for this symposium raises a critical issue: what does it mean for law to act against obesity? To make sense of this question, and the kinds of answers it elicits, it is helpful to keep three broad themes in mind.

The first theme is the ethical and philosophical justification for using law to influence the determinants of obesity. Law is a controversial player in the field of noncommunicable diseases. Legal strategies for responding to health threats within liberal societies are least controversial when they focus on pathogens and toxins and "external threats" that are either infectious (like drug-resistant tuberculosis, SARS, or bird flu) or which create the risk of sudden and catastrophic harm to society at large (like bioterrorism). Obesity, on the other hand, literally embodies the daily choices that individuals make, and invites the response that people should be left alone to live their private lives as they see fit. Law needs to justify its role in the shadow of pervasive assumptions about non-interference with individual preferences - and the accompanying ethic of personal responsibility for choices made - that characterizes the liberal state [23-25].

The second theme relates to how, in a conceptual sense, law fits into a public health framework for obesity prevention. Discussion of law and obesity, like law's role in tobacco control, tends to gravitate towards specific, "hot button" issues. But how can we understand the possibilities of law as a policy tool within a broader framework that links these legal strategies with the determinants of obesity?

An effective response to population weight gain begins, but does not end, with clear strategies. It is also critically important to sell policy ideas effectively in the realm of politics. There is an important literature about the factors that prompt political action on public health issues, including obesity, and the importance of framing policy ideas effectively $[26,27]$.

The third theme relates to the detail of specific laws that seek to respond to obesity. While the detail will vary between different countries, and jurisdictions, obesity prevention is a shared challenge. Experimentation with legal and regulatory approaches to obesity prevention is likely to increase, and there is a great deal to learn from a comparative approach.

The articles in this symposium engage in different ways with each of these three themes. A/Professor James Hodge, from the Johns Hopkins Bloomberg School of Public Health, and co-authors Andrea Garcia and Supriya Shah, open the symposium with a review of legal strategies concerning obesity in the United States [13]. Professor Robyn Martin, from the University of Hertfordshire, and a visiting Professor at the Chinese University of Hong Kong, writes about what is unique to the food and eating culture of the United Kingdom, and the law's evolving role in obesity policy in England [28].

Dr Gary Sacks, and co-authors Mark Lawrence and Boyd Swinburn from the School of Exercise and Nutrition Science at Deakin University present a conceptual framework for systematically locating the roles of local, state and Commonwealth government in policies across the food system and physical activity environments [29]. In a separate article, Professor Boyd Swinburn, from the World Health Organization's Collaborating Centre for Obesity Prevention at Deakin University, identifies law and regulation as one of several broad areas in which leadership from governments is required. In addition to redressing factors that contribute to obesogenic environments, and supporting obesity prevention, there are opportunities for legal and policy efforts to work synergistically with other "movements" for policy action [30].

Drawing on strategies used in environmental regulation, Professor Stephen Sugarman, from the University of California, Berkeley, and Nirit Sandman, present a novel approach to regulating food manufacturers in order to achieve reductions in childhood obesity [31]. A/Professor Elizabeth Handsley, and co-authors Kaye Mehta, John Coveney and Chris Nehmy, from Flinders University, evaluate the criteria that could be used for regulating food advertising to children on television [32]. Their analysis is central to the design of effective regulation of children's food advertising, an issue which is gaining momentum in Australia and beyond. 
In part 1 of a two-part article, A/Professor Roger Magnuson, from the Faculty of Law, University of Sydney, provides a model for understanding the role of law in preventing population weight gain [33]. Part 2 provides a systematic review of possible interventions for law in obesity prevention [34].

How law can best contribute to reducing the health burden of obesity and other lifestyle risk factors for the chronic diseases that Australians overwhelmingly get sick and die from remains one of the most profound challenges that public health law faces in the twenty-first century. The articles in this symposium are by no means an exhaustive review. Law's proper role will continue to be discovered, debated and refined in coming decades.

\section{References}

I. Mello M, Rimm E, Studdert D: The McLawsuit: the Fast-Food Industry and Legal Accountability for Obesity. Health Affairs 2003, 22:207-16.

2. Daynard R: Legal Approaches to the Obesity Epidemic. Consumer Policy Review 2003, 13:154-158.

3. Kersh R, Morone J: Obesity, Courts and the New Politics of Public Health. Journal of Health Politics, Policy and Law 2005, 30:839-868

4. Frank T: A Taxonomy of Obesity Litigation. University of Arkansas at Little Rock Law Review 2006, 28:427-44I.

5. Courtney B: Is Obesity Really the Next Tobacco? Lessons Learned from Tobacco for Obesity Litigation. Annals of Health Law 2006, I5:6I-106.

6. Hodge J: Law as a Tool to Improve the Health of Children and Adolescents in Schools. Journal of School Health 2006, 76:442-445.

7. Alderman J, Smith J, Fried E, Daynard R: Application of Law to the Childhood Obesity Epidemic. Journal of Law, Medicine \& Ethics 2007, 35:90-112.

8. Peterson K, Fox M: Addressing the Epidemic of Childhood Obesity through School-Based Interventions: What Has Been Done and Where Do We Go from Here? Journal of Law, Medicine \& Ethics 2007, 35: I I3-130.

9. United Kingdom Parliament, House of Commons Health Committee: Obesity (HC 23-I) [http://www.parliament.the-sta tionery-office.co.uk/pa/cm200304/cmselect/cmhealth/23/2302.htm]. (accessed 28 April 2008

10. New Zealand. House of Representatives: Inquiry into Obesity and Type 2 Diabetes in New Zealand. Report of the Health Committee 2007 [httwww.parliament.nz/en-NZ/SC/Reports/d/8/ 48DBSCH SCR3868 Inquiry-into-Obesity-and-Type-Two-Diabetesin-New.htm]. (accessed 28 April 2008)

II. Mello M, Studdert D, Brennan T: Obesity - The New Frontier of Public Health Law. New England Journal of Medicine 2006, 354:260I-2610.

12. Gostin L: Law as a Tool to Facilitate Healthier Lifestyles and Prevent Obesity. Journal of the American Medical Association 2007, 297:87-90.

13. Hodge J, Garcia A, Shah S: Legal Themes Concerning Obesity Regulation in the United States: Theory and Practice. Australia \& New Zealand Health Policy in press.

14. Terris M: The Complex Tasks of the Second Epidemiologic Revolution: The Joseph W. Mountin Lecture. Journal of Public Health Policy 1983, 4:8-24.

15. Nestle M, Jacobson M: Halting the Obesity Epidemic: A Public Health Policy Approach. Public Health Reports 2000, I I 5: I 2-24.

16. French S, Story M, Jeffery R: Environmental Influences on Eating and Physical Activity. Annual Review of Public Health 200I, 22:309-335.

17. Brownson R, Haire-Joshu D, Luke D: Shaping the Context of Health: A Review of Environmental and Policy Approaches in the Prevention of Chronic Diseases. Annual Review of Public Health 2006, 27:341-370.
18. Lean M, Gruer L, Alberti G, Sattar N: Obesity - Can We Turn the Tide? British Medical Journal 2006, 333:| 26I-I 264.

19. Zimmet P, James W: The Unstoppable Australian Obesity and Diabetes Juggernaut. What Should Politicians Do? Medical Journal of Australia 2006, 185: 187-188.

20. Perdue W, Mensah G, Goodman R, Moulton A: A Legal Framework for Preventing Cardiovascular Diseases. American Journal of Preventive Medicine 2005, 29(5SI): I39-145.

21. Sullum J: The War on Fat: Is the Size of Your Butt the Government's Business? Reason 2004, 8:20-31.

22. Epstein R: What (Not) to Do About Obesity: A Moderate Aristotelian Answer. Georgetown Law Journal 2005, 93: I36I-I 386.

23. Gostin L: Public Health Law: Power, Duty, Restraint, Berkeley University of California Press; 2000.

24. Magnusson R: Mapping the Scope and Opportunities for Public Health Law in Liberal Democracies. Journal of Law, Medicine \& Ethics 2007, 35:57I-587.

25. Leichter H: 'Evil Habits' and 'Personal Choices': Assigning Responsibility for Health in the 20 $0^{\text {th }}$ Century. The Milbank Quarterly 2003, 81:603-626.

26. Oliver T: The Politics of Public Health Policy. Annual Review of Public Health 2006, 27: 196-233.

27. Kersh R, Morone J: The Politics of Obesity: Seven Steps to Government Action. Health Affairs 2002, 21 : I 42-153.

28. Martin R: The Role of Law in the Control of Obesity in England: Looking at the Contribution of Law to a Healthy Food Culture. Australia \& New Zealand Health Policy in press.

29. Sacks G, Swinburn B, Lawrence M: A Systematic Policy Approach to Changing the Food and Physical Activity Environments to Prevent Obesity. Australia \& New Zealand Health Policy 5:I3.

30. Swinburn B: Obesity Prevention: The Role of Policies, Laws and Regulations. Australia \& New Zealand Health Policy 5:12.

31. Sugarman SD, Sandman N: Using Performance-Based Regulation to Reduce Childhood Obesity. Australia \& New Zealand Health Policy in press.

32. Handsley E, Mehta K, Coveney J, Nehmy C: Regulatory Axes on Food Advertising to Children on Television. Australia \& New Zealand Health Policy in press.

33. Magnusson R: What's Law Got to Do With It? Part I: A Framework for Obesity Prevention. Australia \& New Zealand Health Policy 5: 10

34. Magnusson R: What's Law Got to Do With It? Part 2: Legal Strategies for Healthier Nutrition and Obesity Prevention. Australia \& New Zealand Health Policy 2008, 5: II.

Publish with Bio Med Central and every scientist can read your work free of charge

"BioMed Central will be the most significant development for disseminating the results of biomedical research in our lifetime. "

Sir Paul Nurse, Cancer Research UK

Your research papers will be:

- available free of charge to the entire biomedical community

- peer reviewed and published immediately upon acceptance

- cited in PubMed and archived on PubMed Central

- yours - you keep the copyright 